\title{
Reforma eclesial e mística da fé
}

\author{
Ecclesial reform and mystical faith
}

Mario de França Miranda

\section{Resumo}

O texto procura mostrar como o papa Francisco faz da experiência de fé, da experiência de acolher a Deus que se doa ao ser humano, o núcleo mesmo do cristianismo e de uma renovação eclesial. Subjacente a esta visão está uma concepção do homem a partir de Jesus Cristo e a fé como opção existencial pelo mistério de Deus, fundamento de qualquer discurso sobre Deus. Nesta perspectiva se entende a valorização da religiosidade popular pelo papa Francisco.

Palavras-chave: Experiência cristã. Renovação eclesial. Religiosidade popular.

\begin{abstract}
The text seeks to demonstrate how Pope Francis makes of the experience of faith, of the experience of welcoming God who gives himself to humanity, the true nucleus of Christianity and of ecclesial renewal. Underlying this vision is a conception of the human being starting from Jesus Christ and faith as an existential option through the mystery of God, the basis for any discourse about God. This perspective is meant to give value to the popular piety of Pope Francis.
\end{abstract}

Keywords: Christian experience. Ecclesial renewal. Popular piety. 


\section{Introdução}

Experimentamos hoje como mudou a vida numa sociedade marcada pela aceleração do tempo, pelo bombardeio contínuo de novas informações, pela hegemonia de uma racionalidade de tipo funcional, pelo livre pluralismo de mentalidades e opiniões, pela consequente erosão de valores e de referências sólidas, pela ambiguidade do sagrado no âmbito social, enfim, fatores estes que levaram muitos de nossos contemporâneos a viverem num mundo fechado a qualquer realidade transcendente, como tão bem analisou Charles Taylor ${ }^{1}$. Para completar o quadro poderíamos acrescentar o afã por dinheiro, a impiedosa concorrência professional, o excesso de horas de trabalho, a aceleração da vida cotidiana, tudo provocando uma superficialidade de vida e um consumismo desenfreado. Reconheçamos também que nesta platitude unidimensional da atual sociedade emergem vozes, algumas delas sem referência alguma a Deus, que clamam por justiça no mundo, que anseiam por sentido em suas vidas, que denunciam a destruição do meio ambiente, que se comprometem com os mais pobres e que lutam pela paz em nosso planeta.

Por outro lado, sem que possamos generalizar, convivemos com uma Igreja moldada estruturalmente com forte influência do feudalismo, da época da cristandade, com seus acertos e deficiências, cristalizados em devoções, práticas e ritos, bem como num predomínio do doutrinal, do jurídico e do estritamente hierárquico. O Papa Francisco em sua Exortação Apostólica Evangelii Gaudium denuncia já certa ênfase no administrativo, no sacramental, no institucional (EG 63) que pode gerar uma Igreja mundana sob vestes espirituais ou uma aparência religiosa vazia de Deus (EG 97). Em nossa atual sociedade tais características dificultam sobremaneira que a Igreja seja captada em sua autêntica verdade, em sua realidade salvífica, em sua missão de propagar o Reino de Deus e de humanizar a sociedade. A renovação eclesial passa necessariamente por uma nova configuração institucional ${ }^{2}$, mantidos seus componentes teológicos provenientes da revelação, que permita melhor transparecer a comunhão dos fiéis, a participação ativa de todos seus membros, a incumbência missionária de todo batizado.

\footnotetext{
${ }^{1}$ TAYLOR, C. Uma Era Secular. São Lopoldo/RS: Ed. Unisinos, 2010, pp. 634-696.

${ }^{2}$ Sobre esta noção, ver: MIRANDA, M. F. A Igreja numa sociedade fragmentada: escritos eclesiológicos. São Paulo: Loyola, 2006, pp. 128-139; MIRANDA, M. F. “A configuração eclesial latino-americana: iniciativa do Espírito para a Igreja Universal?”. Revista Teología 52 (2015), pp. 118s.
} 
Nossa reflexão pretende abordar apenas um ponto que nos parece central para uma autêntica reforma da Igreja. Poderíamos justifica-lo a partir da valorização da experiência pessoal como referência mais confiável na atual inflação de discursos que se relativizam e mutuamente se destroem. Entretanto o motivo decisivo que nos levou à escolha deste tema provém da própria fé cristã. $\mathrm{O}$ cristianismo nasceu da experiência salvífica dos primeiros discípulos com a pessoa de Jesus Cristo. E é esta experiência de Deus que mantém viva a fé cristã ao longo da história. Faltando este encontro pessoal com Deus, este acolhimento consciente de sua autodoação divina, a Igreja estaria reduzida a realidades externas que não se sustentam a si mesmas sem estarem referidas a este núcleo experiencial presente na vivência da fé. Tentação forte, pois nos detemos mais facilmente no que é visível, mensurável, explicável, do que naquilo que se situa num nível mais profundo da realidade e das pessoas, tentação essa também atuante quando consideramos a Igreja.

Iniciaremos apresentando como o Papa Francisco demonstra ter captado este desafio da atual sociedade ao enfatizar a mística da fé como elemento fundamental em sua reforma eclesial. Numa segunda parte vamos fazer emergir a fundamentação teológica das afirmações deste papa. Primeiramente oferecendo o fundamento primeiro de toda a nossa reflexão, a saber, a concepção cristã do ser humano. Em seguida examinando como nesta antropologia concebida à luz da revelação estão implicados Jesus Cristo e o Espírito Santo. No interior deste quadro salvífico de fundo aparecerá a fé vivida como uma experiência mistica primordial, presente, atuante e decisiva tanto na reflexão teológica quanto na pastoral da Igreja. Somente então poderemos melhor compreender e valorizar a insistência do Papa Francisco em prol de uma vivência autêntica da fé por parte dos cristãos.

\section{A mística da fé: coração da reforma eclesial de Francisco}

Para Francisco o núcleo da fé cristã está "no amor salvífico de Deus manifestado em Jesus Cristo" (EG 36), constituindo seu "anúncio fundamental" (EG 128) e o centro da evangelização e da reforma da Igreja (EG 164). Este anúncio é anterior a qualquer obrigação moral e religiosa (EG 165) ${ }^{3}$. Ter fé consiste em acolher este amor primeiro, em "responder a Deus que nos ama e salva" (EG 39), que nos dá o sentido da vida (EG 8) e uma alegria profunda

\footnotetext{
${ }^{3}$ SPADARO, A. Entrevista exclusiva do Papa Francisco. São Paulo: Paulus/Loyola, 2013, p.
} 22. 
(EG 7). Nesta experiência iluminada pela pessoa e pela vida de Jesus Cristo nasce "uma relação pessoal e comprometida com Deus" (EG 91), experiência esta que faz do cristão um evangelizador (EG 120).

Deste modo o Papa reconhece o perigo de termos uma Igreja encerrada em estruturas, normas e hábitos (EG 49), com predomínio do aspecto administrativo e sacramentalista (EG 63), podendo acabar "submersa pelo mundanismo espiritual, dissimulado em práticas religiosas, reuniões infecundas ou discursos vazios" (EG 207). Seu objetivo é o que ele expressa como "recriar a adesão mística da fé" (EG 70). Pois sabe que é inútil querer transmitir uma imensidade de doutrinas a força de insistir (EG 35). Pois "não é possível empenhar-se em coisas grandes apenas com doutrinas, sem uma mística que nos anima, sem uma moção interior que impele, motiva, encoraja e dá sentido à ação pessoal e comunitária" (LS 216).

Naturalmente o Papa não esconde que acolher na fé e na vida o amor gratuito de Deus nos leva a fazer de nossa vida uma aventura, porque Deus é e será sempre mistério para o ser humano que jamais pode abarcá-LO num conceito, mas que pode ser encontrado no próprio caminhar da vida de fé. Basta que façamos uma leitura à luz da fé em nossas vidas para detectarmos a presença atuante de Deus em nossa história, embora de modo misterioso. Nas palavras do próprio Papa: "A atitude correta é a agostiniana: procurar a

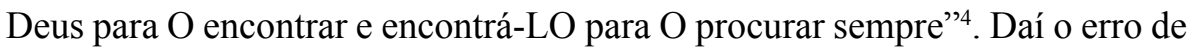
querer fixar Deus numa tradição, numa visão estática, numa segurança doutrinal, fazendo da fé uma ideologia, pois Deus está na vida de cada pessoa. Daí também a necessidade do discernimento ${ }^{5}$. Pois Deus está presente nas casas, ruas e praças da cidade, pois "acompanha a busca sincera que indivíduos e grupos efetuam para encontrar apoio e sentido para a sua vida. Ele vive entre os citadinos promovendo a solidariedade, a fraternidade, o desejo de bem, de verdade, de justiça" (EG 71). Não podemos reduzir a missão a um projeto empresarial ou a uma organização humanitária, pois "o Espírito Santo trabalha como quer, quando quer e onde quer" (EG 279). Importante mesmo é nele confiarmos, invocando-o constantemente e "permitindo que Ele nos ilumine, guie, dirija e impulsione para onde Ele quiser" (EG 280). Pois a ação do Espírito desperta nas pessoas e nos povos a ânsia de conhecer a verdade acerca de Deus, do ser humano, da libertação do mal. Pois todos fomos criados para

\footnotetext{
${ }^{4}$ SPADARO, A., Entrevista, p. 28.

${ }^{5}$ Ibid., p. 29.
} 
o que nos propõe o conteúdo essencial do Evangelho: o amor a Deus e o amor fraterno (EG 265).

Naturalmente a atração exercida por Deus, através do Espírito Santo, em todos os seres humanos se mostra nos "inúmeros sinais da sede de Deus, do sentido último da vida, ainda que muitas vezes expressos implícita ou negativamente" (EG 86). Porque "a fé conserva sempre um aspecto de cruz, certa obscuridade que não tira a firmeza da adesão" (EG 42). E também pode se expressar erradamente num "consumismo espiritual à medida do próprio individualismo doentio", num culto a "Jesus Cristo sem carne e sem compromisso com o outro", com "propostas alienantes" que "não humanizam", a tal ponto que "mais do que o ateísmo, o desafio hoje é responder adequadamente à sede de Deus de muitas pessoas" (EG 89).

Daqui podemos entender a ênfase do Papa no valor da religiosidade popular enquanto tem como protagonista o próprio Espírito Santo (EG 122), responsável pelo instinto da fé (sensus fidei) (EG 119) ${ }^{6}$, e enquanto traduz uma sede de Deus que somente os pobres e os simples podem experimentar, capacitando-os para a generosidade e o sacrifício (EG 123). Trata-se, portanto, realmente de uma "mística popular", expressa por símbolos simples, porém acentuando "mais o credere in Deum que o credere Deum" (EG 124), a saber, a reta intencionalidade da fé ao acolher a oferta salvífica de Deus na força do Espírito, proporcionando-lhe uma singular força missionária.

Já que a fé cristã é o acolhimento não de ideias, mas do próprio Deus que se doa a nós, este acolhimento implica também de nossa parte uma doação a Deus na pessoa de nosso próximo. Com isso crescemos no conhecimento de Deus (1 Jo 4,7), descobrimos algo de novo sobre Deus (EG 272), e sobretudo demonstramos a autenticidade da nossa fé, pois "uma fé autêntica, que nunca é cômoda ou individualista, comporta sempre um profundo desejo de mudar o mundo, transmitir valores, deixar a terra um pouco melhor depois de nossa passagem por ela" (EG 183). Não podemos ficar prisioneiros somente de ideias ineficazes, que "classificam e definem, mas não empenham" (EG 232). A Palavra se encarnou em Jesus e deve continuar se encarnando ao longo da história, através de obras de justiça e caridade nas quais Ela se torna fecunda (EG 233). Pois "uma relação pessoal e comprometida com Deus nos compromete ao mesmo tempo com os outros" (EG 91). Daqui podemos entender a

\footnotetext{
${ }^{6}$ VITALI, D. "Una Chiesa di popolo: il sensus fidei come principio dell'evangelizzazione". In: YANEZ, H. M. (Ed.). Evangelii gaudium: il texto ci interroga. Itália: Gregorian \& Biblical Press, 2014, pp. 53-66.
} 
afirmação do Papa Francisco, tão importante em nossa atual cultura imanente e submissa ao consumismo: "Estou convencido de que, a partir de uma abertura à transcendência, poder-se-ia formar uma nova mentalidade política e econômica que ajudaria a superar a dicotomia absoluta entre a economia e o bem comum social" (EG 205).

Se fossemos sintetizar a concepção evangelizadora do Papa Francisco, sua compreensão da atividade missionária da Igreja, sua visão da própria vida cristã, podemos afirmar que ela deve partir de uma experiência pessoal de Deus, de uma vida transfigurada pelo Espírito Santo, de uma pastoral que arranca de uma mística, a mística de um Deus que é amor e misericórdia, fonte de alegria e de paz (EG 6) e que constitui a realidade que devemos levar aos demais (EG 264).

\section{A teologia subjacente aos pronunciamentos do Papa Francisco}

Em qualquer pronunciamento do magistério eclesiástico, em qualquer exposição da fé, em qualquer pregação cristã que não se contente em repetir trechos da Escritura, estará inevitavelmente embutida uma concepção teológica, uma compreensão ampla e sistematizada do rico e variado manancial oferecido pelos textos sagrados. É função do teólogo fazer emergir esta compreensão de fundo que não só justifique o texto do magistério, mesmo eventualmente apontando suas lacunas, mas sobretudo valorizando suas afirmações feitas numa linguagem mais pastoral ao apresentar as sérias e profundas bases teológicas das mesmas. Este é o nosso objetivo nesta segunda parte deste estudo.

\subsection{A concepção cristã do ser humano}

Quando nos perguntamos pela razão última de nossa existência, ou em outras palavras, porque fomos criados, devemos reconhecer que tudo devemos ao amor absolutamente livre e gratuito de Deus que nos chamou à existência. Pois, sendo Ele a autodeterminação absoluta, Deus não pode ser movido por nada fora de si. Existimos, portanto, porque Deus quis que participássemos de sua felicidade. A humanidade, e o universo como seu entorno, expressam já o amor infinito de Deus por suas criaturas, fato este que não passou desapercebido a muitos místicos cristãos. Mas a revelação nos diz mais.

Pois a pessoa de Jesus Cristo em sua vida, palavras e ações, em seu en- 
sinamento e em seu comportamento revela um relacionamento peculiar com Deus, a quem invoca como seu Pai e para o qual orienta toda a sua existência. Mais em concreto implica este relacionamento que Jesus é distinto do Pai a quem se submete, a quem entrega sua vida, a quem reconhece como o único Deus. Sua missão consistiu exatamente em levar toda a humanidade a reconhecer e acolher esta soberania de Deus, a participar da realização do Reino de Deus, tal como nos atestam os Evangelhos.

Porém em Jesus Cristo encontramos não só o relacionamento do homem Jesus com seu Pai, mas também o relacionamento do Filho eterno de Deus no interior da Trindade. Pois este relacionamento filial é simultaneamente do âmbito criado e do âmbito intradivino, já que tudo o que afirmamos da segunda Pessoa da Trindade tem aqui seu fundamento; de fato, não dispomos de outro acesso à pessoa do Filho eterno de Deus. Aceita esta afirmação podemos examiná-la não na nossa, mas na perspectiva de Deus. Então aparece que o Filho eterno do Pai, enquanto distinto do Pai, pôde sair de Deus Trino ao se encarnar e conservando sua eterna atitude filial tornar possível e fundamentar a existência dos seres humanos que, como Cristo, conscientemente reconheçam também a Deus como Pai e para Ele vivam. Por igual razão, enquanto entorno necessário e condição de possibilidade da existência da humanidade, também todo o restante mundo criado ${ }^{7}$.

Assim o Filho eterno de Deus é a razão de ser da humanidade de Jesus enquanto criada, e é também a razão de ser de toda humanidade e de toda a realidade criada, como nos ensina o Novo Testamento (1 Cor 8,6; $\mathrm{Cl} 1,15$ 18a; Jo 1,1-3). Observemos ainda que o amor do Pai, responsável por toda a criação, é o mesmo amor que tem por seu Filho desde toda a eternidade. Pois o primeiro destinatário do amor do Pai é seu próprio Filho e, em seu Filho, todas as demais criaturas. Portanto este amor que nos alcança é sempre intermediado por seu Filho, seu dinamismo é essencialmente paternal, sendo que nossa resposta ao mesmo deve ser sempre filial, semelhante à de Jesus de Nazaré. Aqui temos um critério decisivo para a autenticidade da fé cristã. Uma fé no Deus de Jesus Cristo, uma fé plasmada na fé de Cristo ( $\mathrm{Hb} \mathrm{12,2})^{8}$, uma fé crística.

\footnotetext{
${ }^{7}$ PANNENBERG, W. Systematische Theologie II. Göttingen: Vandenhoeck\&Ruprecht, 1991, pp. 34-49 (edição brasileira: PANNENBERG, W. Teologia Sistemática II. São Paulo: Paulus/ Academia Cristã, 2009, pp. 50-61).

${ }^{8}$ BALTHASAR, U. von. La foi du Christ. Paris: Paris, 1968, pp. 13-79; SOBRINO, J. Cristologia a partir da América Latina. Petrópolis/RJ: Vozes, 1983, pp. 106-157.
} 
Deste modo a afirmação veterotestamentária de que o ser humano foi criado à "imagem de Deus" (Gn 1,26), deve ser completada por S. Paulo que nos assevera ser Jesus Cristo a imagem de Deus $(2$ Cor 4,4$)$ e, somente como "imagens de seu Filho" (Rm 8,29) participam os seres humanos da semelhança com Deus. O cristianismo antigo considerava assim Cristo como arquétipo à imagem do qual foi criado o primeiro homem. Diríamos hoje que nossa matriz é Jesus Cristo. Daí a importante declaração do Concílio Vaticano II: "Cristo manifesta plenamente o homem ao próprio homem e lhe descobre sua altíssima vocação" (GS 22). Portanto a compreensão cristã do ser humano nos diz que ele é alguém ontologicamente voltado para Deus, à semelhança de Jesus Cristo. Este fato diz respeito a todos os seres humanos e antecede qualquer adesão ou recusa de cunho religioso.

Entretanto o quadro ainda não está completo. Vejamos. Por estarmos inseridos numa tradição ocidental do cristianismo e sem pretendermos entrar na questão do "Filioque", acostumamo-nos a uma pneumatologia cristológica, na qual o Espírito Santo procede do Pai e do Filho e é enviado pelo Filho em vista da economia salvífica. Porém ao examinarmos atentamente os Evangelhos constatamos que o Espírito esteve presente e atuante também durante toda a vida de Jesus. Primeiramente, na linha dos profetas e dos "homens de Deus" considerados portadores do Espírito de Javé, Jesus expulsava demônios e curava enfermos porque a "força" de Deus ou o "Espírito" de Deus estava com ele (Mc 5,30; Lc 11,20; Mt 12,28).

A narração do batismo demonstra que esta presença do Espírito não se dava só temporariamente nas curas, mas era uma realidade permanente na vida de Jesus já no início de sua missão pelo Reino (Mc 1,11) e que irá acompanhá-lo sempre, impelindo-o ao deserto (Mc 1,12) e inspirando-o em toda sua atividade (Lc 4,18; At 10,38). Aqui está implícita uma experiência de Jesus com o Espírito tornando-o consciente de sua vocação e missão. Neste Espírito acontece também o relacionamento do Pai com Jesus (meu Filho muito amado) e de Jesus com o Pai (Abba, Pai). Portanto sua livre entrega na paixão e na morte de cruz aconteceu "em virtude do Espírito eterno" (Hb 9,14). E é este mesmo Espírito que o ressuscita dos mortos (Rm 1,1-4; $1 \mathrm{Tm} 3,16 ; 1 \mathrm{Pd} 3,18)$. Assim Cristo se torna "espírito vivificante" (1 Cor 15,45), a saber, Cristo ressuscitado vive do e no Espírito eterno e o divino Espírito da vida atua nele e por Ele. Deste modo Cristo passa a ser o "Espírito vivificante" e o Espírito passa a ser o "Espírito de Jesus Cristo" (Rm 8,9; Gl 4,6). Enquanto ressuscitado Cristo envia (Jo 16,7), sopra (Jo 20,22) e derrama o Espírito (At 2,23). 
Por conseguinte, a ação do Espírito experimentada pelos primeiros cristãos é marcada por Cristo, leva-os a se relacionarem com Cristo, a reconhecer Cristo como Senhor (1 Cor 12,3), a acolher na fé pela experiência do Espírito a oferta salvífica de Deus em seu Filho. A fé é obra do Espírito o qual, entretanto, não é visto, como também não vemos os olhos com que enxergamos.

Esta cristologia pneumatológica equilibra uma pneumatologia cristológica dominante na tradição ocidental. Pois o Pai é Aquele que envia o Espírito (Jo 14,16; 14,26), o qual pode então ser confessado como "o Espírito da verdade que procede do Pai" (Jo 15,26). Deste modo podemos afirmar que o Pai gera o Filho em virtude do Espírito eterno e sopra o eterno Espírito na presença do Filho. Pois se o Espírito procede do Pai, este proceder pressupõe o Filho já que o Pai só é Pai em sua relação com o Filho. Se o Filho é gerado pelo Pai, o Espírito acompanha a geração do Filho e através dele se manifesta ${ }^{9}$. Deus enquanto Trindade em seu ser e em sua ação salvífica também deverá estar presente e ser fator determinante na resposta do ser humano ao gesto divino de se auto doar. É o que veremos a seguir.

\subsection{A fé como resposta do ser humano à autodoação de Deus}

Portanto o ser humano tem sua identidade última em sua vocação divina, em ser interlocutor de Deus, em acolher este Deus amor que o atrai. Mas este é o Deus manifestado em Jesus Cristo e experimentado no Espírito Santo. Portanto, a abertura do ser humano ao Transcendente, sua sede de infinito e de perfeição, é determinada trinitariamente, se é realmente cristã.

Enfatizemos novamente que este anseio, esta nostalgia, este élan, não pode ser eliminado de uma adequada antropologia sem que se desfigure o próprio ser humano. Pois este desejo de Deus é essencial ao ser humano, embora ele não o tenha por direito e nem seja capaz de satisfazê-lo por suas próprias forças. Trata-se apenas de uma capacidade de acolher, vazia e impotente para adquirir o que deseja. O "éros" não se opõe ${ }^{10}$ à "ágape", pois apenas exprime a condição humana, pressuposto para a recepção gratuita do amor de Deus. Assim se evita tanto o extrinsecismo quanto o imanentismo.

A fé é a resposta do ser humano a esta atração de Deus possibilitada pelo próprio Deus. Sob a ação do Espírito Santo e à semelhança de Jesus Cristo o

\footnotetext{
${ }^{9}$ MOLTMANN, J. O Espírito da Vida. Uma pneumatologia integral. Petrópolis/RJ: Vozes, 2010, p. 77.

${ }^{10}$ BENTO XVI, PP. Carta Encíclica Deus Caritas Est. São Paulo: Paulinas, 2005, n 7.
} 
ser humano confia, se abandona, se deixa dispor e orientar por Deus, já presente em sua sede de absoluto. A fé possui inevitavelmente uma dimensão que poderíamos chamar de mística, num sentido amplo, mas intrínseco à própria fé cristã. Pois sendo Deus Transcendente é Ele Mistério para o ser humano. E como vimos anteriormente que a criação tem na encarnação do Filho de Deus o seu fundamento último, encarnação esta que é obra do Espírito Santo (Lc 1,35), o acolhimento do Mistério que é Deus se revelou em Jesus Cristo na fidelidade ao Espírito nele presente e atuante. Jesus Cristo não desfaz o Mistério de Deus já que Deus não se submete à lógica humana (Mt 20,1-16) e se revela sub contrario na fraqueza, no escândalo e na loucura da cruz aos que têm fé (1Cor 1,18-31). Portanto também em Jesus Cristo Deus permanece

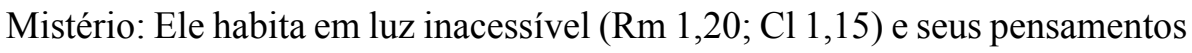
são insondáveis ( $\mathrm{Rm} 11,33)$.

Portanto a revelação é o desvelar-se do mistério de Deus como mistério de amor, como mistério de uma liberdade absolutamente soberana, como mistério que se doa sem perder sua transcendência. Aquele que crê não "sabe" mais sobre Deus, mas tem plena lucidez sobre o mistério de Deus e sobre sua ignorância. Ele interpreta o élan que o habita à luz da pessoa de Jesus Cristo (Jo 1,9), embora constate a seu redor outras interpretações desta mesma realidade, seja em sistemas filosóficos, seja em tradições religiosas. Importante aqui é reconhecer e valorizar a dimensão mística inerente à própria fé enquanto opção voltada para o Mistério de amor que é Deus, porque por Ele previamente atraída. Não podemos conceber a vida cristã desprovida de sua dimensão mística ${ }^{11}$ e a pastoral da Igreja deveria estar muito mais atenta a esta verdade em seus objetivos e planificações. Nas palavras de Bento XVI: "a fé cresce quando é vivida como experiência de um amor recebido e é comunicada como experiência de graça e de alegria" ${ }^{12}$ Também a Palavra de Deus é sempre uma interpelação de amor, uma entrega divina de si. Ela interpela a criatura humana, plasma sua existência e lança-a num itinerário jamais completamente terminado nesta vida ${ }^{13}$, pois a experiência de fé provoca novas experiências sempre se superando em direção ao Deus sempre maior ${ }^{14}$

\footnotetext{
${ }^{11}$ LUBAC, H. de. Sur les chemins de Dieu. Paris: Aubier, 1966, p. 193: "L'élan mystique n'est pas un luxe. Sans lui, la vie morale risque de n'être qu'un refoulement, l'ascèse une sécheresse, la docilité un sommeil, la pratique religieuse une routine, une ostentation ou une peur".

${ }^{12}$ BENTO XVI, PP. Carta Apostólica Porta Fidei. São Paulo: Paulinas, 2012, n 7.

${ }^{13}$ Ibid., $\mathrm{n}^{\circ} 6$.

${ }^{14}$ RATZINGER, J. Les Principes de la Théologie Catholique. Paris: Tequi, 1982, pp. 384-393.
} 
Observemos ainda que a fé cristã por estar voltada para Deus que é transcendente e mistério necessita de símbolos que a identifiquem, a expressem, a celebrem. De fato, o símbolo aponta para além de si próprio, embora partilhe em si mesmo a realidade simbolizada, de tal modo que esta está nele presente e atuante ${ }^{15}$. Podemos mesmo dizer que tudo no cristianismo é simbólico: a Bíblia, os sacramentos, a comunidade eclesial, os dogmas de fé, a pregação, as celebrações, já que ultrapassando sua materialidade remetem o ser humano para o Mistério de Deus. Sendo Deus Mistério de amor são tais símbolos sinais salvíficos que devem ser captados e aceitos como tais. Deste modo se faz necessária e urgente toda uma pedagogia cristã, catequese mistagógica diziam os antigos, que possibilite a postura realmente cristã na escuta da Palavra de Deus e na celebração dos sacramentos, especialmente da eucaristia. $\mathrm{O}$ sinal é sempre mediação e convite para a experiência salvífica. Caso contrário ficamos retidos na exterioridade do sinal, não chegamos realmente a Deus, não vivemos a mística da fé. Conhecemos os sinais, mas para nós eles não são realmente salvíficos.

\subsection{Fé, mística e teologia}

A relação entre a mística da fé e a teologia é bem mais íntima do que poderíamos imaginar ${ }^{16}$. Pois, sendo Deus transcendente e mistério para o ser humano, qualquer discurso sobre Deus que mereça o nome de teo-logia deve arrancar da experiência fundante da fé ao acolher a amorosa e gratuita autodoação divina por ação do próprio Deus (Espírito Santo) em nós. Esta experiência que não se deixa enunciar é a que nos permite expressar este Mistério em enunciados, numa palavra, fazer teo-logia ${ }^{17}$. Esta é e será sempre segunda, já que a presença da ação de Deus no que crê é afinal o que fundamenta o discurso teológico. O vivido antecede o crido: lex orandi, lex credendi. A teologia não só se alimenta da mística, mas sua função não é propriamente esclarecer o mistério (tarefa impossível), mas alimentar a fé do cristão levando-o a reconhecer e a adorar o Mistério que o atrai. Neste sentido a teologia está a serviço da mística, já que a revelação de Deus não consiste num pacote de ver-

\footnotetext{
${ }^{15}$ HAIGHT, R. Dinâmica da Teologia. São Paulo: Paulinas, 2004, pp. 149-167.

${ }^{16}$ Nesta questão ver DUMAS, B. Mystique et Théologie d'après Henri de Lubac. Paris: Cerf, 2013.

${ }^{17}$ RAHNER, K. Über den Begriff des Geheimnisses in der katholischen Theologie. Schriften zur Theologie IV. Einsiedeln: Benzinger, 1960, p. 70.
} 
dades, mas na vinda de Jesus Cristo, mistério de Deus a nós doado. Acolher na fé este mistério é a tarefa central da teologia, já que neste mistério da pessoa de Jesus Cristo estão os demais mistérios (Ef 3,4s) ${ }^{18}$.

Daí decorrem igualmente os limites do labor teológico, pois este jamais conseguirá traduzir o mistério para o conceito, torná-lo submisso aos limites da razão, penetrá-lo em sua profundidade. As verdades de fé, os dogmas cristãos, enquanto enunciados a nosso alcance, serão sempre passíveis de compreensões mais ricas, que nunca saciarão a inteligência humana. Todo discurso teológico, enquanto teo-lógico, é um discurso inacabado, é uma expressão da verdade divina tendendo para a mesma ${ }^{19}$, contendo formulações que podem ser ultrapassadas e impedem encerrar uniformemente a verdade divina num sistema fechado. Cada geração descobre sua plenitude na vivência e na experiência sempre novas, sem querer imobilizá-la no tempo, mas reconhecendo a historicidade de nossa percepção e a riqueza insondável do mistério cristão ${ }^{20}$. Tentação aqui seria a teologia querer fixar o mistério de Cristo em personagens acessíveis, em quadros interpretativos transitórios, que nos satisfazem, mas que nos impedem o acesso ao mistério e à sua autêntica vivência.

O dinamismo anagógico para o Mistério que nos atrai torna o trabalho teológico para a compreensão da fé uma luta sem fim, fadada à derrota, mas aceita com paz e alegria. É um lançar-se num oceano sem esperança de atingir a outra margem, pois ela não existe. Pois Deus está presente sem ser visto, é encontrado quando ainda o buscamos. Estamos às voltas com uma inteligência espiritual da verdade revelada já que acontece pela ação do Espírito Santo, podendo deste modo ser encontrada na fé dos mais simples. Também fica clara a distinção entre teologia e ciências da religião, já que estas últimas não partem da fé, da experiência do Mistério, da iluminação que dele provém, sendo, entretanto, úteis e pertinentes em seu campo epistemológico, mas falhando quando se aventuram para além do mesmo.

\footnotetext{
${ }^{18}$ Ver já numa perspectiva sacramental, mas com uma pertinência ainda maior: TABORDA, F. "Da celebração à teologia. Por uma abordagem mistagógica da teologia dos sacramentos". Revista Eclesiástica Brasileira 64 (2004), pp. 588-615.

19 "Perceptio veritatis revelatae tendens in ipsam". Expressão assumida por TOMÁS DE AQUINO, S. Th. II-II, q.1, a.6, sed contra (AQUINO, S. T. Suma de Teología. 2a ed. Madrid: Biblioteca de Autores Cristianos, 1989, 5 vol.).

${ }^{20}$ RATZINGER, J. Comentário ao texto da Comissão Teológica Internacional El Pluralismo Teológico. Madrid: BAC, 1976, pp. 15-20.
} 
O nosso tema está intimamente relacionado com o conhecido "sensus fidei”, sobre o qual já existe uma abundante bibliografia ${ }^{21}$ de modo que não trataremos explicitamente desta questão. Interessa-nos, isto sim, considerá-la na mesma ótica seguida até aqui. Pois constatamos que emerge fortemente da bibliografia anterior uma mesma perspectiva de leitura, a saber, de cunho mais cognoscitivo e doutrinal. Naturalmente tal compreensão do sentido da fé, já presente na tradição da Igreja e recentemente valorizada pelo Concílio Vaticano II (LG 12), é perfeitamente justa e de modo algum pode ser omitida. Dela decorre a riqueza da fé de todo o Povo de Deus que ultrapassa mesmo as expressões da teologia ou do magistério eclesiástico ${ }^{22}$, atua no desenvolvimento da doutrina e da prática cristã, na contribuição do laicato para a fé da Igreja, na mútua relação entre magistério e teologia, na transmissão da fé (DV 8). Mesmo sem pretendermos enunciar todas as consequências desta leitura mais generalizada, já podemos avaliar sua importância para a vida da Igreja. Entretanto faz-se mister enfatizar uma outra dimensão do sentido da fé no horizonte até aqui apresentado da autodoação de Deus amor. Vejamos.

Já que todo e qualquer ser humano é constituído enquanto tal por um élan voltado para o Absoluto e como este Absoluto consiste num Deus que é autodoação amorosa e que o interpela por uma resposta, atingindo tal autodoação divina o íntimo, o coração de cada pessoa, então sua aceitação na fé não diz respeito somente à inteligência, mas alcança todas as demais faculdades humanas, e mais concretamente a própria afetividade. A inquietação do ser humano, para usar uma formulação agostiniana, provém de sua própria constituição antropológica, antes mesmo que ele busque expressá-la em conceitos, palavras e imagens. Como vimos anteriormente a acolhida do gesto divino na fé é a base necessária para todo discur-

\footnotetext{
${ }^{21}$ Ver a extensa bibliografia apresentada TERRA, D. O Sentido da fé. Lisboa: Universidade Católica Editora, 2009, pp. 137-142, ou o amplo estudo sobre o tema por parte de BEINERT, W. "Der Glaubenssinn der Gläubigen in Theologie - und Dogmengeschichte. Ein Überblick". In: WIEDERKEHR, D. (Hrsg.). Der Glaubenssinn des Gottesvolkes. Konkurrenz oder Partner des Lehramts?. Freiburg: Herder, 1994, pp. 66-131. Mais recentemente dispomos do texto da COMISSÃO TEOLÓGICA INTERNACIONAL. O Sensus Fidei na vida da Igreja. São Paulo: Paulinas, 2015.

22 RAHNER, K. Dogmatische Randbemerkungen zur "Kirchenfrömmigkeit". Schriften zur Theologie V. Einsiedeln: Benzinger, 1962, pp. 391s.
} 
so posterior sobre Deus. Quanto mais autêntica for esta acolhida, quanto mais concretizada na vida for esta fé, quanto mais plenificada na caridade, maior será a percepção do infinito amor de Deus em seu íntimo. Mas esta percepção não dissolve o Mistério que é Deus, daí que suas expressões são sempre inacabadas, abertas a leituras complementares, dóceis à ação livre do Espírito Santo ${ }^{23}$, pois a Igreja "tende continuamente para a plenitude da verdade divina" (DV 8).

A cultura fechada de nossos dias não consegue enxergar a pertinência de uma realidade transcendente que traga sentido para a vida humana, cultura esta que põe em crise as representações tradicionais de Deus e que limita a noção de ciência ao que é objeto de experiência controlável. Este horizonte cultural pede da Igreja uma atenção maior à experiência da fé do indivíduo, que se dá na comunidade eclesial e chega a sua realização no amor ao próximo, na doação de si ao Outro e aos outros, em correspondência com a autodoação divina que é afinal o amor infinito. Pois a fé em Deus nos descentra de nós mesmos, leva-nos a viver diante do Mistério, liberta-nos de nossas certezas e seguranças, sensibiliza-nos para as carências de nossos próximos, lança-nos na ação capaz de remediá-las.

Naturalmente a experiência do Mistério na fé poderá ser tematizada com expressões diversas conforme os contextos socioculturais ao longo da história, embora elas permaneçam sempre aquém do que procuram exprimir. Mesmo que reconheçamos a necessidade das formulações para a identidade da fé cristã, mais importante é a experiência mais primordial que as faz surgir por estar voltada para o próprio Deus. Pois a tensão espiritual da fé é "o lugar interior das proposições de fé, irrealizáveis sem este movimento interior"24. Daqui o valor da religiosidade popular que, na simplicidade ingênua de suas expressões conserva a referência a Deus, dá testemunho de sua fé e mostra-se mais sensível aos valores evangélicos da partilha e da solidariedade ${ }^{25}$. Portanto a insuficiente formação cristã de muitos dos mais simples pode conviver com uma autêntica vida de fé, com expressões que nos desconsertam, pois são as mediações disponíveis para se relacionarem com Deus. No cristianismo a vida é mais importante que o discurso.

\footnotetext{
${ }^{23}$ TERRA, D., ob. cit., p. 68.

${ }^{24}$ RATZINGER, J. Comentário ao texto da Comissão Teológica Internacional O Pluralismo Teológico. São Paulo: Loyola, 2002, p. 23.

${ }^{25}$ PAULO VI, PP. Exortação Apostólica Evangelii Nuntiandi. São Paulo: Paulinas, 1975, n 48.
} 


\section{Conclusão}

Para o Papa Francisco aparece com muita clareza que não haverá uma eficaz reforma da Igreja sem uma vivência pessoal e autêntica da fé cristã. Pois nesta experiência salvífica do encontro do ser humano com Deus que é amor temos não só o "centro da fé cristã" e o fator que explica o nosso seguimento de Cristo $^{26}$, mas também a razão de toda a ação pastoral da Igreja ${ }^{27}$. No passado notou-se, por várias razões, certa ênfase no aspecto doutrinal, moral e jurídico da fé por parte da Igreja. Hoje, diante de uma sociedade tão sofrida e tão injusta, tão carente de sentido e de valores, a Igreja deve manifestar o rosto misericordioso de Deus, deve ser acolhedora para poder levar nossos contemporâneos a um encontro com Deus em Jesus Cristo. Neste encontro então experimentarão o sentido de vida e a paz que tanto buscam. Neste encontro provarão a mística da fé, a ação do Espírito de Cristo que os leva ao outro necessitado. Neste encontro serão testemunhas do Transcendente, portadores de sentido, transmissores da bondade divina. Terão experimentado a fé existencialmente como realidade gratificante e salvífica. Terão encontrado o Deus que é misericórdia e nos transforma para sermos também misericordiosos, deixando aflorar em nossa vida e em nossa pastoral a ternura de Deus ${ }^{28}$. Oxalá possamos trabalhar com o Papa Francisco em seu empenho em fortalecer a mística da fé e renovar a Igreja Católica.

\section{Referências bibliográficas}

AQUINO, S. T. Suma de Teología. 2a ed. Madrid: Biblioteca de Autores Cristianos, 1989 (5 vol.).

BALTHASAR, U. von. La foi du Christ. Paris: Paris, 1968.

BENTO XVI, PP. Carta Apostólica Porta Fidei. São Paulo: Paulinas, 2012.

BENTO XVI, PP. Carta Encíclica Deus Caritas Est. São Paulo: Paulinas, 2005.

BEINERT, W. "Der Glaubenssinn der Gläubigen in Theologie - und Dogmengeschichte. Ein Überblick". In: WIEDERKEHR, D. (Hrsg.).

\footnotetext{
${ }^{26}$ BENTO XVI, PP. Carta Encíclica Deus Caritas Est, $\mathrm{n}^{\circ} 1$.

${ }^{27}$ Ibid., $\mathrm{n}^{\circ} 19$.

${ }^{28}$ FRANCISCO, PP. Misericordiae Vultus. São Paulo: Paulinas, 2015, nº 10.
} 
Der Glaubenssinn des Gottesvolkes. Konkurrenz oder Partner des Lehramts?. Freiburg: Herder, 1994.

COMISSÃO TEOLÓGICA INTERNACIONAL. O Sensus Fidei na vida da Igreja. São Paulo: Paulinas, 2015.

DUMAS, B. Mystique et Théologie d'après Henri de Lubac. Paris: Cerf, 2013. FRANCISCO, PP. Misericordiae Vultus. São Paulo: Paulinas, 2015.

HAIGHT, R. Dinâmica da Teologia. São Paulo: Paulinas, 2004.

LUBAC, H. de. Sur les chemins de Dieu. Paris: Aubier, 1966.

MIRANDA, M. F. A Igreja numa sociedade fragmentada: escritos eclesiológicos. São Paulo: Loyola, 2006.

MIRANDA, M. F. A configuração eclesial latino-americana: iniciativa do Espírito para a Igreja Universal? Revista Teología 52 (2015), pp. 117-130.

MOLTMANN, J. O Espirito da Vida. Uma pneumatologia integral. Petrópolis/ RJ: Vozes, 2010.

PANNENBERG, W. Systematische Theologie II. Göttingen: Vandenhoeck\&Ruprecht, 1991 (edição brasileira: PANNENBERG, W. Teologia Sistemática II. São Paulo: Paulus/Academia Cristã, 2009).

PAUlO VI, PP. Exortação Apostólica Evangelii Nuntiandi. São Paulo: Paulinas, 1975.

RAHNER, K. Dogmatische Randbemerkungen zur "Kirchenfrömmigkeit". Schriften zur Theologie V. Einsiedeln: Benzinger, 1962.

RAHNER, K. Über den Begriff des Geheimnisses in der katholischen Theologie. Schriften zur Theologie IV. Einsiedeln: Benzinger, 1960.

RATZINGER, J. Comentário ao texto da Comissão Teológica Internacional El Pluralismo Teológico. Madrid: BAC, 1976 (edição brasileira: RATZINGER, J. Comentário ao texto da Comissão Teológica Internacional O Pluralismo Teológico. São Paulo: Loyola, 2002).

RATZINGER, J. Les Principes de la Théologie Catholique. Paris: Tequi, 1982.

SOBRINO, J. Cristologia a partir da América Latina. Petrópolis/RJ: Vozes, 1983.

SPADARO, A. Entrevista exclusiva do Papa Francisco. São Paulo: Paulus/ Loyola, 2013. 
TABORDA, F. "Da celebração à teologia. Por uma abordagem mistagógica da teologia dos sacramentos". Revista Eclesiástica Brasileira 64 (2004), pp. 588-615.

TAYLOR, C. Uma Era Secular. São Lopoldo/RS: Ed. Unisinos, 2010.

TERRA, D. O Sentido da fé. Lisboa: Universidade Católica Editora, 2009.

VITALI, D. "Una Chiesa di popolo: il sensus fidei come principio dell'evangelizzazione". In: YANEZ, H. M. (Ed.). Evangelii gaudium: il texto ci interroga. Itália: Gregorian \& Biblical Press, 2014.

\section{Mario de França Miranda}

Doutor em Teologia Sistemática pela Pontificia Università Gregoriana (Roma) Professor de Teologia na Pontifícia Universidade Católica do Rio de Janeiro Rio de Janeiro / RJ - Brasil E-mail:mfranca@puc-rio.br

Recebido em: 24/08/16

Aprovado em: 26/08/16 